\title{
沉用FEMコードを利用した鋼一層 門形ラーメンの地震応答解析
}

\author{
酒造敏廣 ${ }^{1} \cdot$ 水澤富作 $^{2} \cdot$ 山田 宰 $^{3} \cdot$ 戸田智規 ${ }^{4}$ \\ 1正会員 神戸市立工業高等専門学校教授 都市工学科（†651-2194 神戸市西区学園東町8-3） \\ E-Mail: tmiki@kobe-kosen.ac.jp \\ 2正会員 大同大学教授 工学部都市環境デザイン学科（干457-8532 名古屋市南区白水町40） \\ E-Mail: mizusawa@daido-it.ac.jp \\ 3正会員 和歌山工業高等専門学校准教授＼cjkstart環境都市工学科（广644-0023 和歌山県御坊市名田町野島77） \\ E-Mail: z-yamada@wakayama-nct.ac.jp \\ 4正会員 川田工業株式会社（干114-8562 東京都北区滝野川1丁目3番11号） \\ E-mail: tomoki.toda@kawada.co.jp
}

\begin{abstract}
本論文は，箱形ばり中間部がせん断崩壊する鋼一層門形ラーメンの地震応答解析を行っている. はり中 央部を汎用非線形構造解析ソルバーのFEMモデルに置換して, 弾塑性有限変位解析プロセスを構築し, オ ンライン実験法に準ずる仮動的な地震応答解析法を論じている. ラーメンの地震応答解析を通じて, 補剛 されたフランジプレートを持つ箱形ばりのせん断崩壊性状，及び，それがラーメン全体の復元力一変位関 係に及ぼす影響を調べている，最後に，柱基部の損傷と履歴エネルギー分担の点から，箱形ばりがせん断 座屈崩壊するラーメンの地震応答の特徵をまとめている.
\end{abstract}

Key Words: steel portal frame, shear collapse of beam, earthquake response, pseudo-dynamic analysis

\section{1. まえがき}

実験・数值計算の 2 つのプロセスをオンラインで結ん で動的解析を行うオンライン実験法（ハイブリッド実験, 仮動的実験とも呼ばれる）は，構造物の地震時崩壊挙動 を調べていく上で, 有効な研究手段になっている ${ }^{1) ~ 77 . ~}$

とくに, 中島ら ${ }^{8)}$ 9) が, 構造物の動的崩壊挙動を取り 扱う時刻歴応答解析に対して「非線形の反復収束計算を 必要とせず, 数值減衰を考慮できる数值積分アルゴリズ ム $\alpha$-OS（オペレータ・スプリッティング）」を発表し て以降，この約 20 年間で，オンライン実験法は大きな 発展を遂げてきた. 最近では，実験と数值計算のプロセ スを自在に組み合わせて，構造物の広範なオンライン実 験・ハイブリッドシミュレーションが実施されつつある (たとえば，文献 7)参照）。

著者らは，兵庫県南部地震（1995）で被害を受けた鋼 製橋脚のうち，はり部材中央がせん断座屈崩壊する門形 ラーメンにオンライン実験法を適用し，その地震応答性 状を調べてきた 10) 12). すなわち，鋼薄板のはり腹板が せん断座屈後, 抵抗せん断力が大きく変動する崩壊挙動
を実験プロセスで再現し，地震応答の数值解析プロセス を通じて，はりのせん断座屈時の柱基部の塑性変形性状 や履歴消費エネルギー分担の特性を明らかにした。また， はり腹板のせん断降伏が先行するラーメンでは, 他部材 との降伏変位差に起因して，せん断崩壊する腹板がエネ ルギー吸収部材となり得る場合があることを示した。

本研究は，箱形ばり中央がせん断座屈崩壊する鋼一 層門形ラーメンを対象にして，これまでの研究の実験 プロセスで対象としたはり中央部を汎用 FEM コードの 一つである非線形構造解析ソルバーMARC ${ }^{13}$ ) (以下, 汎 用 FEM，または MARC と略す）で仮想化し，オンライ ン実験に準じた方法（以下，仮動的解析法と呼ぶ）に よって，地震応答解析を行うものである ${ }^{14)}$. フランジプ レートによる箱形ばりのせん断変形挙動の変動とそれ がラーメンの地震灾答に及ぼす影響等，オンライン実

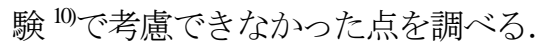




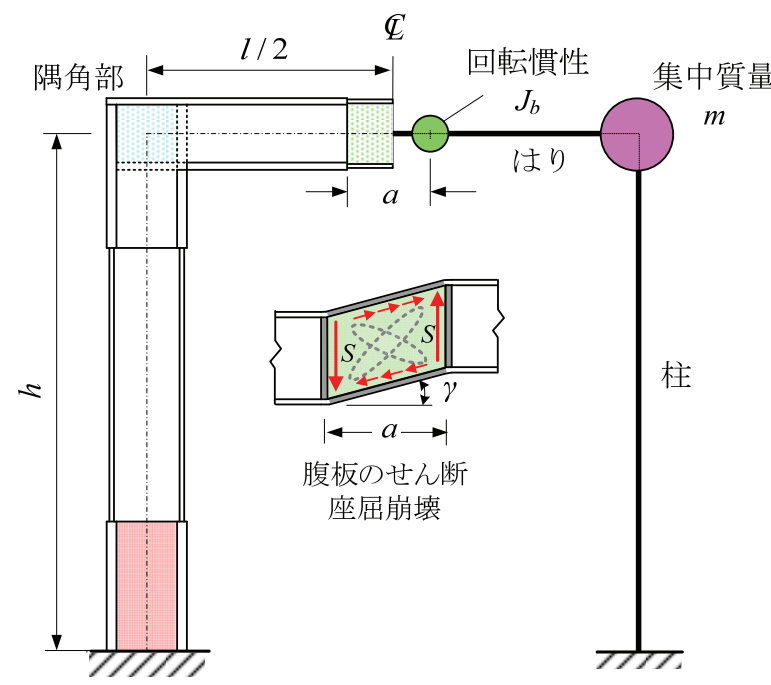

(a) 門形ラーメン

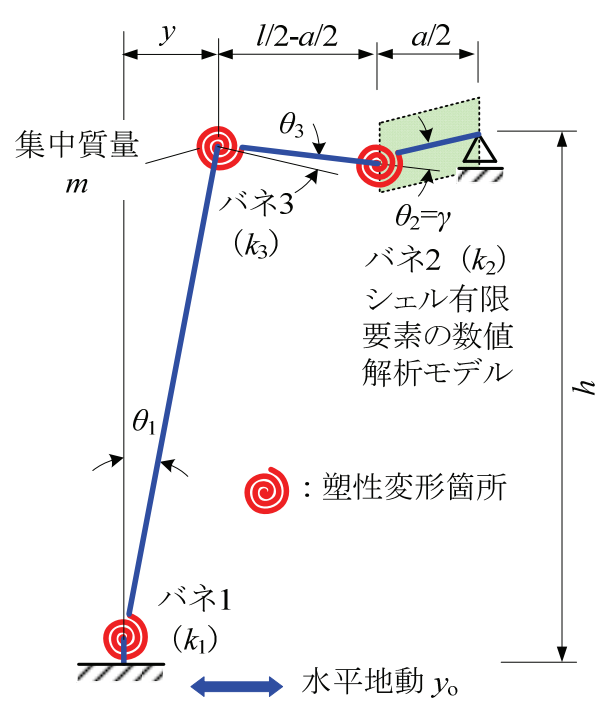

(b) 弾塑性回転バネを組み込んだ動的解析モデル

図-1 はりがせん断崩壊する鋼一層門形ラーメンの解析モデル

\section{2. オンライン実験法に準ずる鋼門形ラーメンの 仮動的な地震応答解析法}

本研究では，図-1(a)に示すように，水平地動を受け， はり中間部がせん断座屈崩壊する鋼一層門形ラーメンを 研究対象としている. ラーメンの解析モデルと運動方程 式，および，数值積分法は，文献 10)と同様である。は り中央の実験モデルを FEM 解析モデルに置換している 点で文献 10) と相違する ${ }^{14)}$. 解析法の概要を説明すると 以下のとおりである.

\section{(1) ラーメン骨組の動的解析モデル}

ラーメンは，はりの曲げ変形の逆対称性を考えて，そ の中央でローラー支持された逆 L 形骨組として取り出 す. 図-1(b)のように，曲げモーメントが卓越する柱基部 と隅角部，および，せん断力が卓越するはり中間部に回 転バネを組み込んだ岡体バネモデルにモデル化する．柱 頭部にはラーメンの水平並進運動に対応する集中質量 $m$, かつ，はり中間部の回転バネ 2 の位置には，運動方程式 において, 腹板のせん断変形角 $\gamma\left(=\theta_{2}\right)$ を陽的に表すた めに，回転慣性 $J_{b}$ を仮定する.

区間 $a$ のはり中間部では，曲げモーメントに比べてせ ん断力が卓越するので，単純せん断状態にあるとみなし， せん断崩壊挙動を表すバネ 2 は, 後述する FEM 解析モ デルにモデル化する. ここで，バネ 2 のモーメント $M_{2}$ と回転角 $\theta_{2}$ は, 腹板のせん断力 $S$, 世ん断変形角 $\gamma$ との 間に次の関係がある.

$$
\begin{aligned}
M_{2} & =S a / 2 \\
\theta_{2} & =\gamma
\end{aligned}
$$

柱基部と隅角部の回転バネ $1 ， 3$ には，図-2 のバイリ

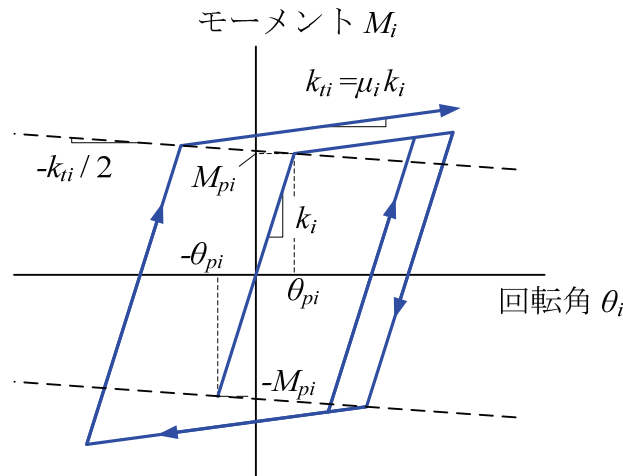

図-2 柱基部と隅角部における回転バネ $k_{i}$ の モーメント $M_{i}$ 一回転角 $\theta_{i}$ 関係 $(i=1,3)$

ニア型の弾塑性 $M-\theta$ 曲線を用いる. この曲線には, 等 方・移動硬化によるひずみ硬化を簡易的に考慮できる負 勾配の補助境界線を仮定している ${ }^{10,11) .}$

\section{（2）運動方程式と数值積分法}

a) $\alpha-O S$ 法の運動方程式

水平外力として地動加速度が門形ラーメンに作用する とき, 時刻 $t_{n+1}$ において, 柱頭部の水平変位 $y$ とバネ 2 の回転角 $\theta_{2}$ を表す変位ベクトル $\mathbf{d}_{n+1}$ に関する運動方程式 は次式で表される ${ }^{9}$.

$$
\begin{aligned}
& \mathbf{M} \ddot{\mathbf{d}}_{n+1}+(1+\alpha) \mathbf{C} \dot{\mathbf{d}}_{n+1}-\alpha \mathbf{C} \dot{\mathbf{d}}_{n} \\
& +(1+\alpha)\left(\mathbf{K}^{I} \mathbf{d}_{n+1}+\mathbf{K}_{n+1}^{E} \tilde{\mathbf{d}}_{n+1}\right)-\alpha\left(\mathbf{K}^{I} \mathbf{d}_{n}+\mathbf{K}_{n}^{E} \tilde{\mathbf{d}}_{n}\right) \\
& \quad=(1+\alpha) \mathbf{P}_{n+1}-\alpha \mathbf{P}_{n}-(1+\alpha) \mathbf{M} \ddot{\mathbf{d}}_{0, n+1}+\alpha \mathbf{M} \ddot{\mathbf{d}}_{0, n}
\end{aligned}
$$

ここに, $\ddot{\mathbf{d}}, \dot{\mathbf{d}}, \mathbf{d}, \mathbf{P}, \ddot{\mathbf{d}}_{0}, \tilde{\mathbf{d}}$ は, 加速度, 速度, 修正 子変位, 外力, 地動加速度, および, 予測子変位の各心゙ クトルである. また， $\alpha$ は数值減衰に関するパラメータ であり-1/3 に設定している ${ }^{92}{ }^{12)}$ ．さらに， $\mathbf{K}^{I}$ は弾性剛性 マトリックス ${ }^{10)}$ である. 


$$
\mathbf{K}^{I}=\left[\begin{array}{cc}
\frac{k_{1}+k_{3}}{h^{2}} & \frac{a}{l h} k_{3} \\
\frac{a}{l h} k_{3} & k_{2}+\frac{a^{2}}{l^{2}} k_{3}
\end{array}\right]
$$

$\mathbf{K}^{E}$ はラーメンの弾塑性挙動の履歴に依存する岡性マト リックス（式(7)参照）である. M は質量マトリックス である ${ }^{10)}$.

$$
\mathbf{M}=\left[\begin{array}{ll}
m & 0 \\
0 & J_{b}
\end{array}\right]
$$

さらに， C は減衰マトリックスであり，1 次， 2 次の振 動モード対する減衰定数を 5\%として，レーリー型を仮 定している.

\section{b) 予測子変位, 復元力, および, 修正子変位ベクト} ルの算定

予測子変位 $\mathbf{d}_{n+1}$ は次式で近似している ${ }^{8)}$.

$$
\tilde{\mathbf{d}}_{n+1}=\mathbf{d}_{n}+\dot{\mathbf{d}}_{n} \Delta t+(1 / 2-\beta) \ddot{\mathbf{d}}_{n} \Delta t^{2}
$$

ここに， $\beta=(1+\alpha)^{2} / 4$ である.

つぎに，予測子変位に対してラーメンの非線形剛性が 分担する見かけ上の復元力 $\mathbf{K}^{\tilde{E}_{n+1}}$ （=不つり合い力）は, 真の復元力 $\mathbf{Q}_{n+1}$ と弾性剛性による復元力 $\mathbf{K}^{\widetilde{I} \mathbf{d}_{n+1}}$ との差と して得られる（図-3参照）。

$$
\mathbf{K}^{E} \tilde{\mathbf{d}}_{n+1}=\mathbf{Q}_{n+1}-\mathbf{K}^{I} \tilde{\mathbf{d}}_{n+1}
$$

ここに

$$
\begin{aligned}
\mathbf{Q}_{n+1}= & \left.\begin{array}{c}
\left(M_{1, n}+M_{3, n}\right) / h \\
M_{2, n}+(a / l) M_{3, n}
\end{array}\right\} \\
& +\left\{\begin{array}{c}
k_{1 n} \Delta \tilde{\theta}_{1, n+1} / h+k_{3 n} \Delta \tilde{\theta}_{3, n+1} / h \\
\Delta M_{2, n+1}+(a / l) k_{3 n} \Delta \tilde{\theta}_{3, n+1}
\end{array}\right\}
\end{aligned}
$$

ここで, $M_{i, j}$ : 時刻 $t_{j}$ におけるバネ $i$ の復元モ一メント, $\Delta \widetilde{\theta}_{i, j}$ : 時刻 $t_{j-1} \sim t_{j}$ におけるバネ $i$ の増分予測子回転角で ある.また， $k_{1 n}, k_{3 n}$ は，図-2のバイリニア $M-\theta$ 関係か ら得られる $t_{n} \sim t_{n+1}$ 間のバネ $1 ， 3$ の割線岡性である.

図-3 に示したように，ラーメンが非線形挙動を呈す るとき，修正子変位に対する不つり合い力が予測子変位 に対するそれで近似できるものとして 6), 8)，式(3)の運動 方程式が成り立つように変位を修正する.

以上に説明した応答解析の流れを図-4 に示す. ラー メン全体の時刻歴応答解析のメイン・プログラムは MARC のユーザー・サブルーチンに組み込んでいる.

上述したように，文献 10)で示したオンライン実験法の 実験プロセスが，次の(3)に述べる静的弾塑性有限変位 解析プロセスに置き代わっているのが特徴である.この ような取り扱いができるのは，時刻歴応答解析で非線形 の反復収束計算を必要としない数值積分アルゴリズム

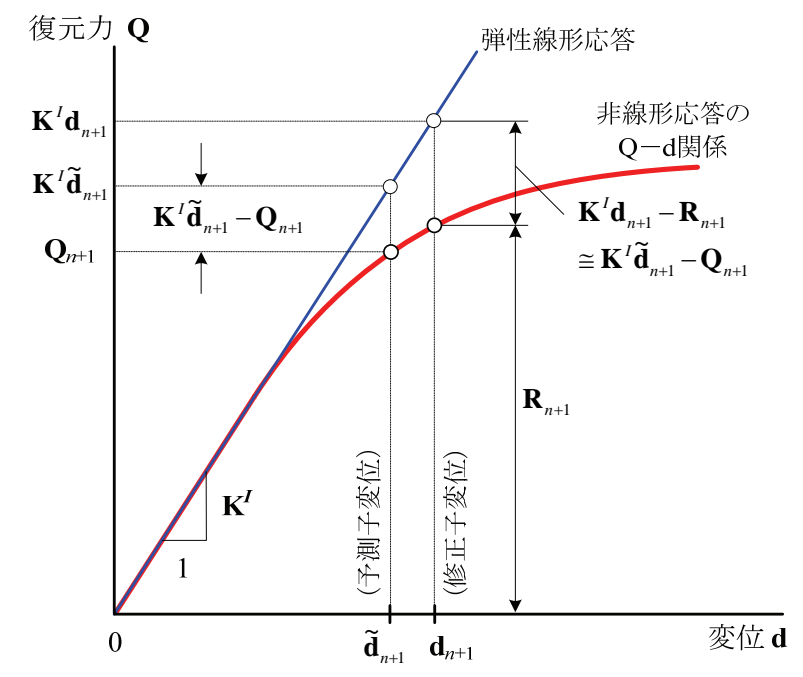

図-3 OS 法の予測子・修正子変位に対応する復元力 と不つり合い力 ${ }^{6}$

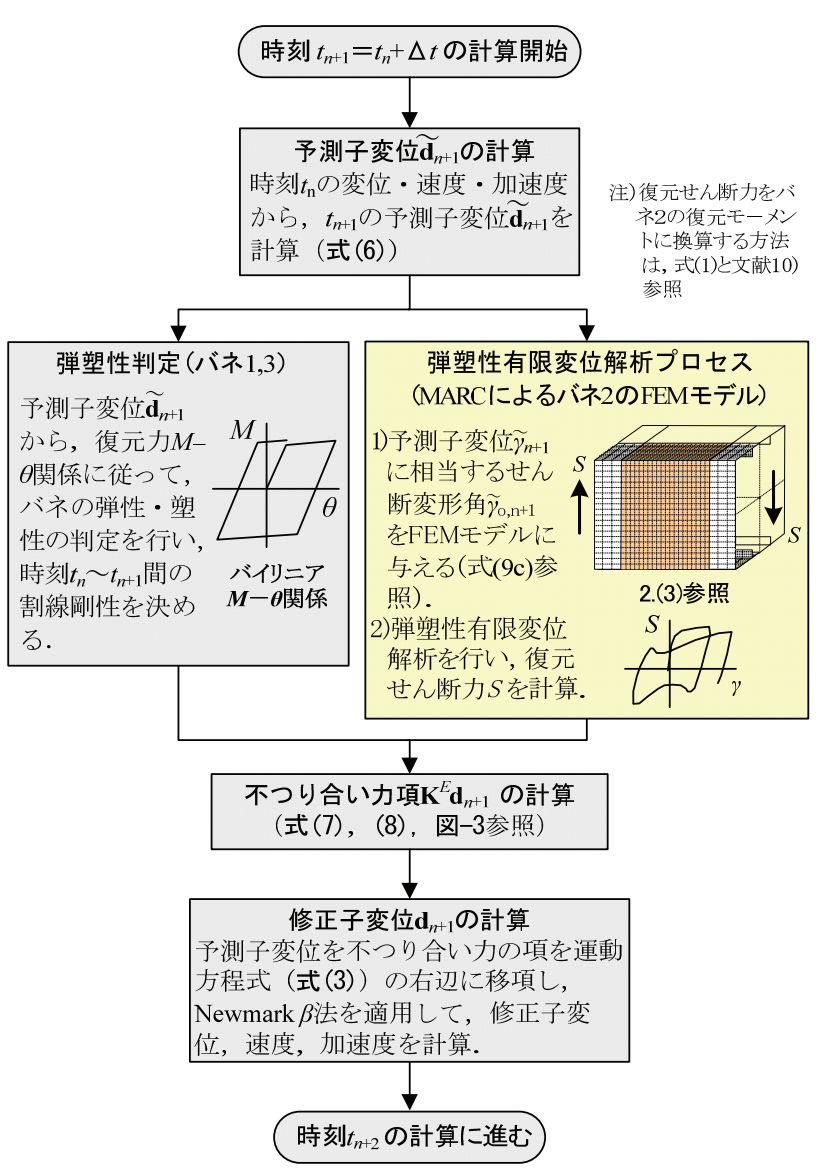

図-4 汎用 FEMによる弾塑性有限変位解析プロセスを 含んだラーメンの時刻歴応答解析の流れ

OS 法 ${ }^{8)}$ 9)を用いていることが大きい.

\section{（3）せん断崩壊するはり中間部に対する弾塑性有限変 位解析のプロセス}

a) FEM 解析モデル

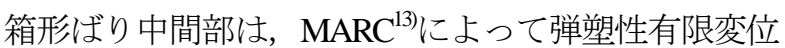
解析を行う。図-5 に示すように，箱形断面の変形の対 


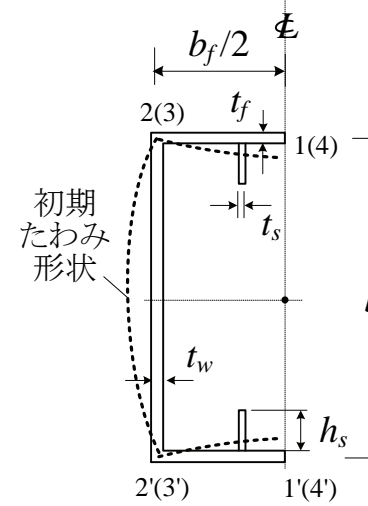

はり中央断面図
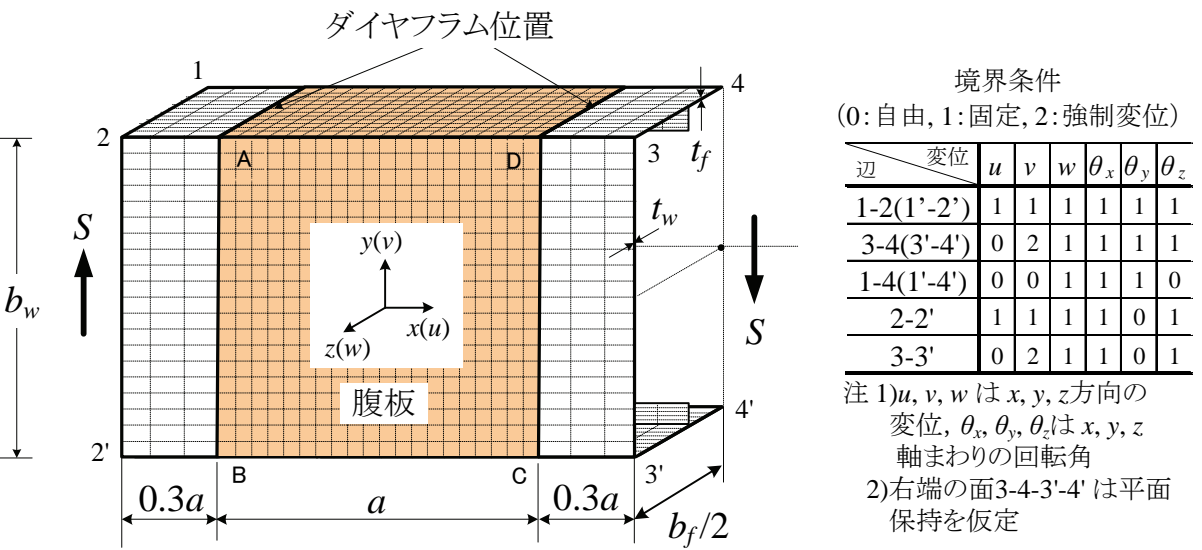

図-5 箱形ばり中央のせん断崩壊を再現するためのパネル延長 FEMモデル

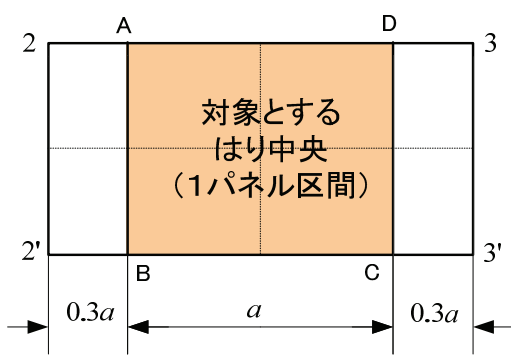

(a) パネル延長モデル

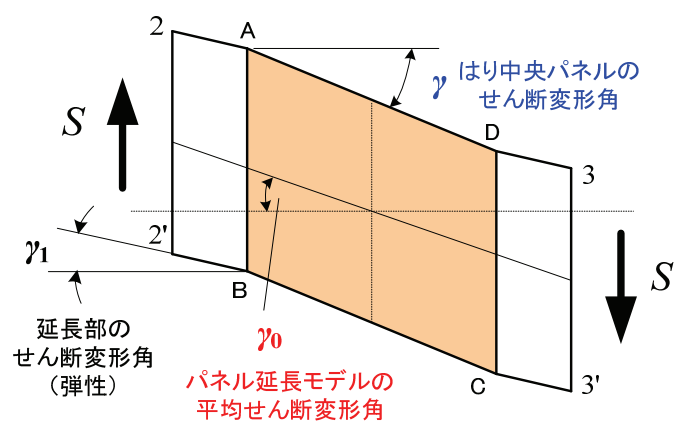

(b) パネル延長モデルと中央パネルのせん断変形図

図-6 パネル延長モデルと中央パネルの せん断変形角の関連付け

称性を利用して，半分のコの字形断面，ダイヤフラムお よび縦補岡材を四節点の薄肉シェル要素でモデル化する. 縦補剛材はスカーラップを通ってダイヤフラムを貫通し ているものとしている．要素分割は図示したとおりであ り，圧縮補岡板と圧縮・曲げを受ける箱形短柱の弾塑性

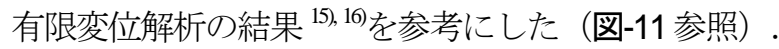

ここで，縦補剛材を持つフランジプレートと腹板をは り中央の区間 $a$ で取り出すと, 縦補剛材の面内変位を拘 束するので，予備解析を通じて，両側に $0.3 a$ だけパネ ルを延長して，長さ $1.6 a$ の箱形ばりを解析対象として いる（以下，パネル延長モデルと言う）。

境界条件は図中に示寸とおりである. 左端の各節点を 固定し，右端の各節点を平面保持した上で鉛直方向に強 制変位を与えてせん断変形させる。 これらは, 武田 ${ }^{17,18)}$ による実験結果から, せん断座屈後に斜め張力場を形成
した I 椼腹板の崩壊状況を参考にしている.

材料の応力一ひずみ曲線は, 塑性域の公配を弾性域の 1/100 とするバイリニア型を基本とし，移動硬化のひず み硬化則を仮定した。はり中央 1 パネルの腹板とフラン ジプレートには，それぞれ最大で $b_{w} / 250 ， a / 1000$ となる 正弦半波形の初期たわみを与えている. なお，残留応力 に相当するひずみは，塑性域での繰り返しによって累積 する塑性ひずみに比して小さいので, 残留応力は考慮し ていない.

\section{b) はり中央パネルのせん断変形角の算出方法}

区間 $a$ のはり中央 1 パネルのせん断変形角 $\gamma$ は，パネ ル延長モデルの変形角 $\gamma_{0}$ と以下に従って関連付けた.

図-6 を参照すると，中央パネル $(\mathrm{A} \sim \mathrm{D})$ と延長部 （2-2'-B-A，3-3-C-D）のせん断変形の幾何学的関係から， 次式が成り立つ。

$$
\gamma=1.6 \gamma_{0}-0.6 \gamma_{1}
$$

ここで， $\gamma_{1}$ は長さ $0.3 \mathrm{a}$ の延長部のせん断変形角である.

本文では，上式を参考にして，中央パネルのせん断変 形角 $\gamma$ を

$$
\gamma=\xi_{1} \gamma_{0}+\xi_{2} \gamma_{1}
$$

の形で近似し，解析モデルごとに弾塑性有限変位解析を 行って, 最小二乗法により, 係数 $\xi_{1}, \xi_{2}$ を定めた. その 際， $\gamma$ は, 対角線 $\mathrm{AC}, \mathrm{BD}$ の伸縮量 $\delta_{\mathrm{AC}}, \delta_{\mathrm{BD}}$ を用いて, 次式で求めている ${ }^{19}$.

$$
\gamma=\frac{\delta_{A C}+\delta_{B D}}{2 a} \sqrt{1+\left(\frac{a}{b_{w}}\right)^{2}}
$$

ラーメンの仮動的解析では, 応答解析から得られる中 央パネルのせん断変形角 $\gamma$ をパネル延長モデルの

$$
\gamma_{0}=\gamma / \xi_{1}-\xi_{2} \gamma_{1} / \xi_{1}
$$

に変換し，それをMARC の FEM解析モデルに入力して 復元せん断力 $S$ を求め, 時刻歴応答解析にフィードバッ クする (図-4参照) . 


\section{c) パネル延長モデルから算出した中央 1 パネルのせん} 断変形角の精度

後述の解析結果（3.(2)参照）から，はり中央の平均せ 几断応力 $\tau$-中央パネルのせん断変形角 $\gamma$ 曲線を求めて, 図-7 に示寸. 式(9b)で算出した $\gamma$ と MARC解析結果を用

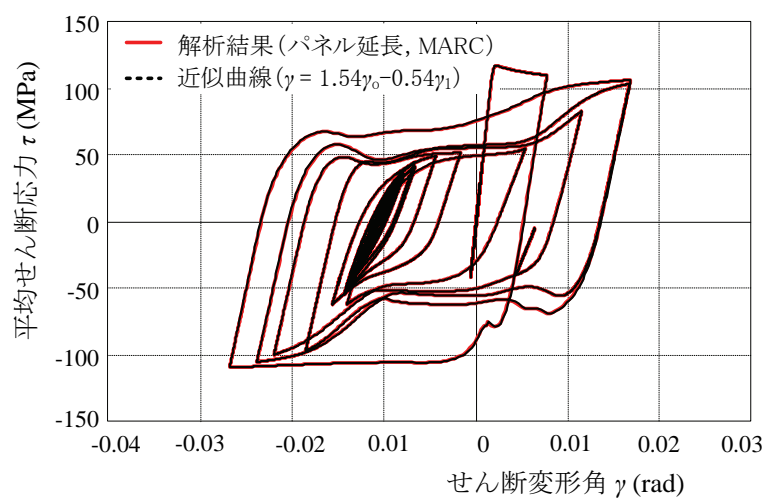

(a) 無補剛フランジプレートの箱形ばり (Case 2)

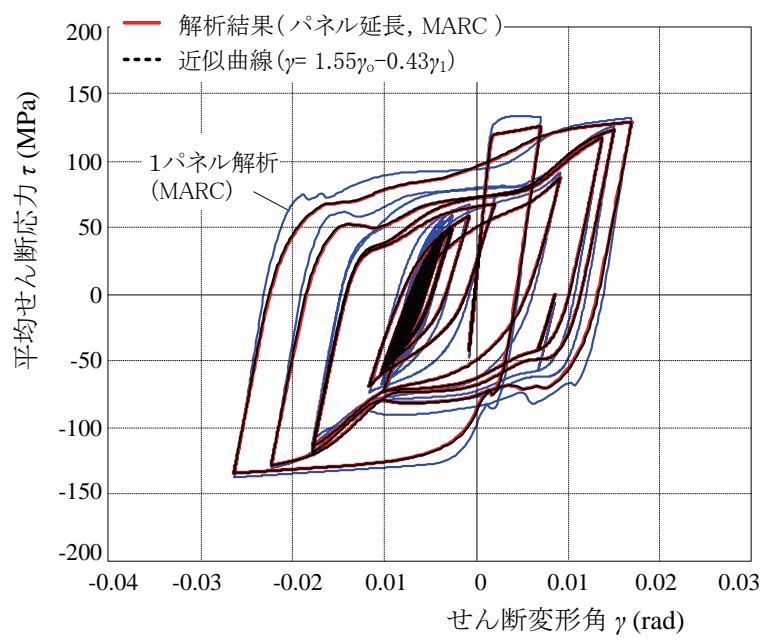

(b) 補剛されたフランジプレートの箱形ばり (Case 4)

図-7 パネル延長モデルと中央パネルのせん断 変形角による $\tau-\gamma$ 曲線の比較
いて式(10)から求めた $\gamma$ を $\tau-\gamma$ 曲線によって比較してい る. 補剛されたフランジプレートに対応寸る同図(b)に は, 区間 $a$ の中央 1 パネルの箱形断面を MARC で解析 した結果（1パネル解析）も示している.

この図からわかるように，フランジプレートの補剛・ 無補剛にかかわらず，式(9b)（図中参照）を用いると， パネル延長モデルの変形角 $\gamma_{0}$ からはり中央パネルの $\gamma$ を 精度よく予測できている. 1 パネル解析の結果では, フ ランジプレートの縦補剛材の面内変形が両端で拘束され るため，抵抗せん断応力が大きく現れている.

なお， $\tau-\gamma$ の処女履歴曲線の弾性勾配は，無補剛およ び補剛のフランジプレートの箱形断面に対して，それぞ れ 66.2GPa，および，67.2GPa となり，せん断弾性係数 $G$ の公称值よりも約 15\%小さい.

\section{(4) 解析モデルの各種諸元}

a) 門形ラーメン

ラーメンの寸法諸元，各部のバネ定数とその塑性モ一 メント，および，解析条件を表-1 に示す，バネ 1３の 弾性バネ不係数 $k_{1} \sim k_{3}$ と塑性モーメント $M_{p 1} \sim M_{p 3}$ の設定方 法は，付録A.1にまとめている.

Case 1 は文献 10)のオンライン結果と比較するための モデルである. Case 1〜5において, 柱高さ $h$ とスパン $l$ はともに $10 \mathrm{~m}$ である. ラーメンの一次, 二次固有周期 $T_{1} ， T_{2}$ は，それぞれ $T_{1}=1 \mathrm{~s} ， T_{2}=0.001 \mathrm{~s}$ である. 柱基部, はり中間部が降伏するときの水平変位を $y_{p 1}$ と $y_{p 2}$ とする と, Case1〜5は次の特徵がある.

- Case 2,4 : はり中間部が柱基部よりも先行して降伏 する場合で, $y_{p 2} / y_{p 1}=0.5$

- Case 1,3,5 : 柱基部とはり中間部が同時に降伏する場 合で, $y_{p 2} / y_{p 1}=1$

表-1 一層門形ラーメンの仮動的解析の入力データ

\begin{tabular}{|c|c|c|c|c|c|c|c|c|c|c|c|c|c|c|}
\hline \multirow{3}{*}{\begin{tabular}{r||} 
項目 \\
Case
\end{tabular}} & \multicolumn{7}{|c|}{ " ラーメンの地震応答解析モデル } & \multicolumn{6}{|c|}{ 箱形ばり中央の FEM モデル } & \multirow{3}{*}{ 備 考 } \\
\hline & \multicolumn{3}{|c|}{$\begin{array}{l}\text { バネ定数 } \\
(\mathrm{GN} \cdot \mathrm{m})\end{array}$} & \multicolumn{3}{|c|}{$\begin{array}{c}\text { 塑性モーメント } \\
(\mathrm{MN} \cdot \mathrm{m})\end{array}$} & \multirow{2}{*}{$\begin{array}{c}\text { 崩壊 } \\
\text { 荷重 } \\
H_{p} \\
(\mathrm{MN}) \\
\end{array}$} & \multicolumn{3}{|c|}{ 腹 板 } & \multicolumn{3}{|c|}{ フランジプレート } & \\
\hline & $k_{1}$ & $k_{2}$ & $k_{3}$ & $M_{p 1}$ & $M_{p 2}$ & $M_{p 3}$ & & $\begin{array}{c}b_{w} \\
(\mathrm{~mm})\end{array}$ & $\begin{array}{c}t_{w} \\
(\mathrm{~mm})\end{array}$ & $R_{\tau}$ & $\begin{array}{c}b_{f} \\
(\mathrm{~mm})\end{array}$ & $\begin{array}{c}t_{f} \\
(\mathrm{~mm})\end{array}$ & $R_{f}$ & \\
\hline 1 & 22.9 & 3.19 & 21.8 & 45.0 & 6.76 & 338 & 7.9 & 200 & 1.35 & 1,54 & 200 & 7.7 & 0.46 & $\begin{array}{l}\text { 無補剛フランジプレー } \\
\text { ト, オンライン実験 }{ }^{10)} \\
\text { との比較 }\end{array}$ \\
\hline 2 & \multirow{4}{*}{44.7} & \multirow{4}{*}{4.18} & \multirow{4}{*}{49.4} & 95.5 & \multirow{4}{*}{7.16} & \multirow{4}{*}{358} & 13.1 & \multirow{4}{*}{2,000} & \multirow{4}{*}{13.2} & \multirow{4}{*}{1.34} & \multirow{4}{*}{2,300} & \multirow{4}{*}{30} & \multirow{2}{*}{1.36} & \multirow{2}{*}{$\begin{array}{l}\text { 無補剛フランジプレー } \\
\text { ト }\end{array}$} \\
\hline 3 & & & & 47.7 & & & 8.4 & & & & & & & \\
\hline 4 & & & & 95,5 & & & 13.1 & & & & & & 0.45 & $\begin{array}{l}\text { 補剛 フランジプレー } \\
\text { 卜，縦補剛材の曲げ岡 }\end{array}$ \\
\hline 5 & & & & 47.7 & & & 8.4 & & & & & & 0.45 & 比は 2 種類 \\
\hline
\end{tabular}

注 1） $h=l=10 \mathrm{~m} \quad$ 2)固有周期 $\left.T_{1}=1 \mathrm{~s}, \quad T_{2}=0.001 \mathrm{~s} \quad 3\right) M-\theta$ 曲線の塑性域勾配 $\mu_{1}=\mu_{2}=0.01 \quad$ 4) Case 1: 質量 $m=1.01 \times 10^{7} \mathrm{~kg}, J_{b}=102.4 \mathrm{~N} \cdot \mathrm{m}^{2}$, Case 2 5: 質量 $m=1.98 \times 10^{7} \mathrm{~kg}, J_{b}=156 \mathrm{~N} \cdot \mathrm{m}^{2} \quad$ 5) せん断変形区間長 $a=2 \mathrm{~m} \quad$ 6)柱基部降伏変位 $y_{p 1}$ : Case 1: 19.7mm, Case 2, 3: 21.4mm, Case 4, 5: 10.7mm 7) 降伏変位比 Case 1, 3, 5: $y_{p 2} / y_{p 1}=1$, Case 2, 4: $y_{p 2} / y_{p 1}=0.5 \quad$ 8) Case 4, 5 の縦補剛材寸法 $\gamma_{1} / \gamma_{1, \text { req }}=3$ のとき $h_{s}=263 \mathrm{~mm}$, $t_{s}=32 \mathrm{~mm}, \gamma_{l} / \gamma_{1, \text { req }}=5$ のとき $h_{s}=307 \mathrm{~mm}, t_{s}=37 \mathrm{~mm}$ 9)無次元幅厚比 腹板 : $R_{\tau}=b_{w} / t_{w} \sqrt{12\left(1-v^{2}\right) \tau_{y} /\left(k_{\tau} E \pi^{2}\right)}, k_{\tau}=9.34$, フランジプレート : $R_{f}=b_{f} / n / t_{f} \sqrt{12\left(1-v^{2}\right) \sigma_{y} /\left(k_{f} E \pi^{2}\right)}, k_{f}=4.0, n:$ 補剛材に囲まれたサブパネル数. 
地震応答解析に用いる地動加速度には，兵庫県南部地 震・神戸海洋気象台観測波の NS 成分の最初の 30 秒間 を用いた。 その際，ラーメン各部の塑性変形の大小を再 現するために，入力加速度を増幅した ${ }^{10}$. 具体的には, 弾性応答の最大水平変位 $y_{\max E}$ が柱基部の降伏変位 $y_{p 1}$ の 何倍になるかを指定し，地震動の増幅率 $y_{\max E} / y_{1}$ を決め た. ここに， $y_{1}$ は，オリジナルの地震波形を用いて計算 した弾性応答の最大変位である.

\section{b) はり中間部の FEM モデル}

はり中間部の解析モデルの寸法諸元も表-1 に示す. 材料定数，降伏点等を表-2 にまとめる. Case 1 の材料定 数は実験值 ${ }^{10)}$ を用いている. Case 2 5 は，はり腹板が一 辺 2,000 $\mathrm{mm}$ の正方形, その無次元幅厚比 $R_{\tau}=1.34$, およ び，フランジプレートの板厚 $30 \mathrm{~mm}$ であり，次の特徽が ある.

・Case 4,5 : 縦補剛材で補剛されたフランジプレート $\left(R_{f}=0.45<0.5\right)$ を持つ箱形ばりである. 縦補岡材 の曲げ岡比 $\gamma_{l}$ は道路橋示方書 ${ }^{20)}$ の必要剛比 $\gamma_{l, \text { req }}$ の 3 倍と 5 倍を仮定している. 腹板の幅厚比は SS400

表-2 はり中央の FEM解析に用いた弾性定数と降伏点

\begin{tabular}{|c|c|c|c|c|c|c|c|}
\hline 項目 & \multicolumn{5}{|c|}{ ダイアフラム間（区間長 $a$ ) } & \multicolumn{2}{|c|}{$\begin{array}{c}\text { 長さ } 0.3 a の \\
\text { 延長部 }\end{array}$} \\
\hline Case & $\begin{array}{c}\text { ヤング } \\
\text { 係数 } E \\
\text { (GPa) }\end{array}$ & $\begin{array}{c}\text { ポアソ } \\
\text { ン比 } \\
v\end{array}$ & $\begin{array}{c}\text { せん断 } \\
\text { 弾性係 } \\
\text { 数 } G \\
\text { (GPa) } \\
\end{array}$ & $\begin{array}{c}\text { 降伏点 } \\
\sigma_{y} \\
(\mathrm{MPa})\end{array}$ & $\begin{array}{c}\text { せん断 } \\
\text { 降伏点 } \\
\tau_{y} \\
(\mathrm{MPa}) \\
\end{array}$ & $\begin{array}{c}\text { 降伏点 } \\
\sigma_{y} \\
(\mathrm{MPa})\end{array}$ & $\begin{array}{c}\text { せん } \\
\text { 断降 } \\
\text { 伏点 } \tau_{y} \\
(\mathrm{MPa}) \\
\end{array}$ \\
\hline 1 & \multirow{2}{*}{206} & \multirow{2}{*}{0.3} & \multirow{2}{*}{79.2} & 293 & 169 & \multirow{2}{*}{355} & \multirow{2}{*}{205} \\
\hline $2 \sim 5$ & & & & 235 & 136 & & \\
\hline
\end{tabular}

材で水平補剛材を必要としない限界幅厚比 ${ }^{20)} の 152$ にほぼ等しい.

• Case 2,3 : 上の Case 4, 5 で縦補剛材を取り除いている. 幅厚比が大きい無補剛フランジプレート（ $R_{f}=$ 1.36）の影響で抵抗せん断力がどの程度低下するの かを調べる.

ダイアフラムは，SS400 材で板厚 $15 \mathrm{~mm}$ としている. 両端のパネル延長部については，板厚は中央部と同じで， フランジプレートと縦補剛材，および，腹板に SM490Y 相当の降伏点を仮定している.

\section{3. はり中央がせん断座屈崩壊する一層門形ラ一 メンの地震応答解析}

\section{(1) 仮動的解析結果とオンライン実験結果 ${ }^{10)}$ との比較}

Case 1 のはり中央のせん断力 $S$ 一世ん断変形角 $\gamma$, 柱基 部のモーメント $M_{1}$ 一回転角 $\theta_{1}$, および, ラーメンの水 平復元力 $H$ 一変位 $y$ の関係を図-8に示古，同図には，は りのバネ 2 に完全弾塑性の $M-\theta$ 関係 $\left(\mu_{2}=0\right)$ を仮定し た解析（以下，バイリニア解析と言う）の結果も示して いる.

この図からわかるように, Case 1 の $S$ - $\gamma$ 曲線では, 才 ンライン実験と比べて，i)腹板がせん断座屈した直後 (除荷・弾性域から曲線が折れ曲がる箇所) の耐力変動 が若干小さく，ii)斜め張力場形成後の耐力上昇は約 $22 \%$ 小さく，せん断降伏に相当するところで頭打ちになり， iii)変形角の応答が若干大きい. $H-y$ 曲線では，i)に起因

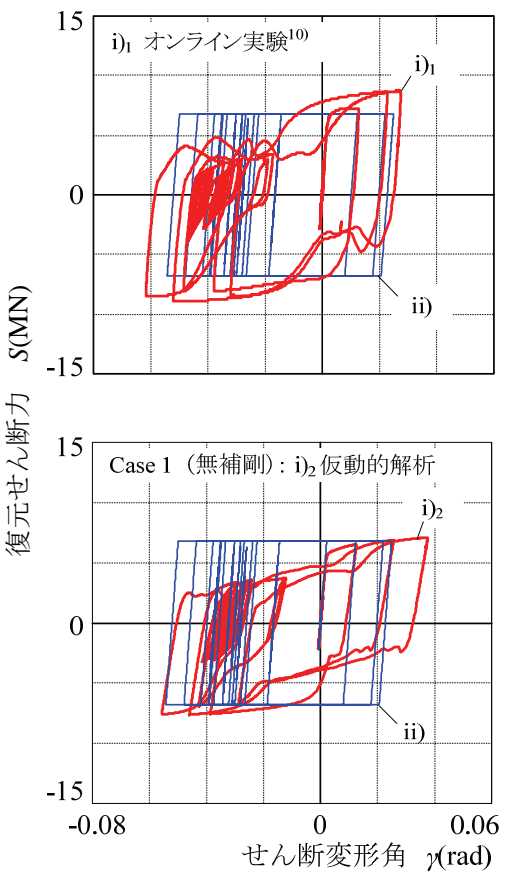

(a) はり中間部の $S-\gamma$ 曲線

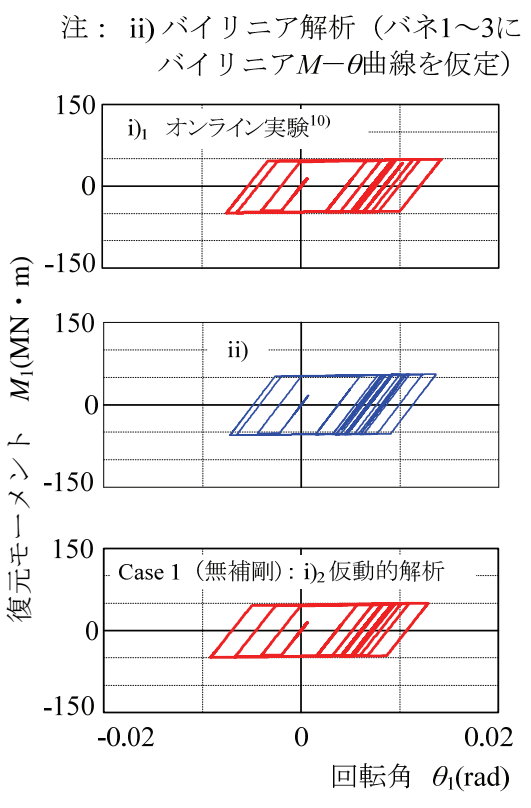

(b) 柱基部の $M_{1}-\theta_{1}$ 関係

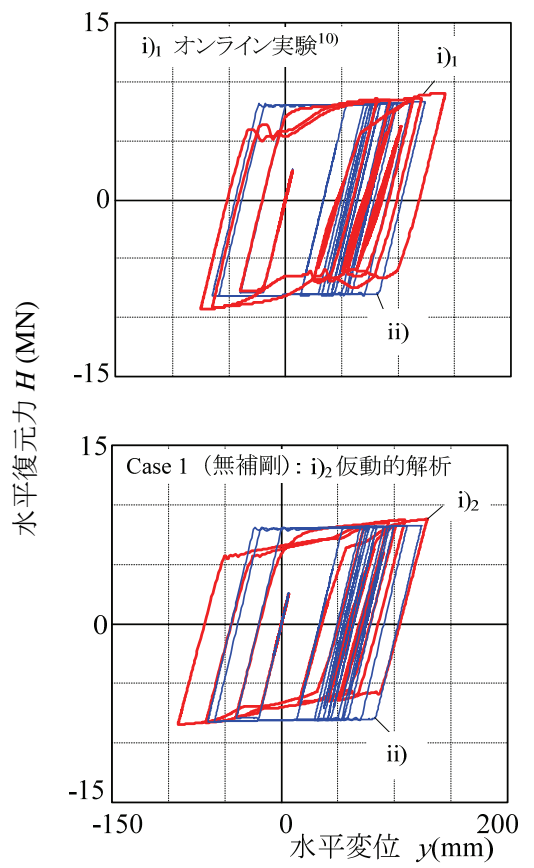

(c) ラーメンの $H-y$ 曲線

図-8 実験プロセスを仮想化した仮動的解析法とオンライン実験法の比較 
して, 非弾性域での耐力変動がオンライン実験に比べて 滑らかになっている.これらの差異は, オンライン実験 では，フランジプレートを剛と仮定したことに起因し， 箱形ばりのフランジプレートの変形挙動が影響している と考える ${ }^{14}$.

\section{(2) 復元力一变位関係に関する解析結果と考察}

はり中間部の降伏が先行する Case 2, 4 で弾性最大応答 変位 $y_{\max } / y_{p 1}=6$ の場合，および，柱基部とはり中間部が 同時降伏する Case 3, 5 で $y_{\max } y_{p 1}=12$ の場合について考察
する. Case 4, 5 のフランジプレートの縦補剛材の曲げ剛 比 $\gamma_{1}$ 必要岡比 $\gamma_{1, \text { req }}$ の3倍としている.

まず，はり腹板のせん断力 $S$ 一せん断変形角 $\gamma$ 曲線, 柱基部の復元モーメント $M_{1}$ 一回転角 $\theta_{1}$ 曲線と累積塑性 回転角の時刻歴応答, および, ラーメンの水平復元力 $H$ 一変位 $y$ 曲線を図-9 に示寸。ここで，柱基部の累積塑性 回転角は，増分塑性回転角 $\Delta \theta_{p 1}$ の絶対值和 $\Sigma\left|\Delta \theta_{p 1}\right|$ を降伏 回転角 $\theta_{y 1}$ で除して表している.

a) はり中央腹板のせん断力 $S$ 一世ん断変形角 $y$ 曲線

各ケースの結果から，はり腹板のせん断座屈に起因し

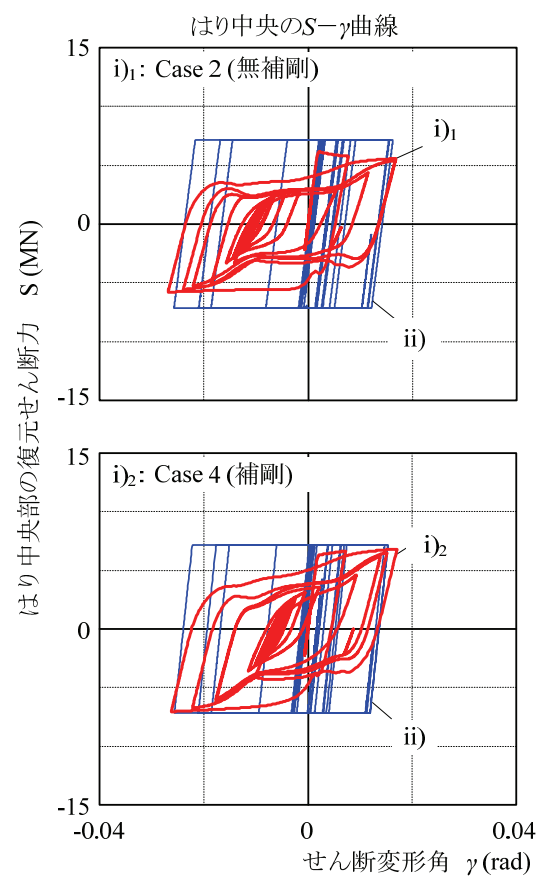

\section{i)仮動的解析 ii) バイリニア解析}

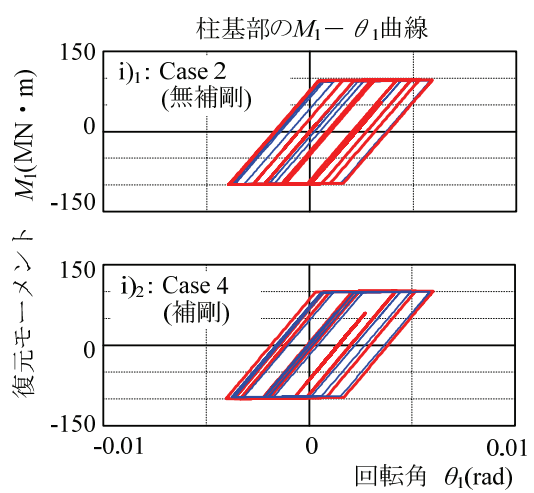

柱基部の累積塑性回転角の時刻歴応答

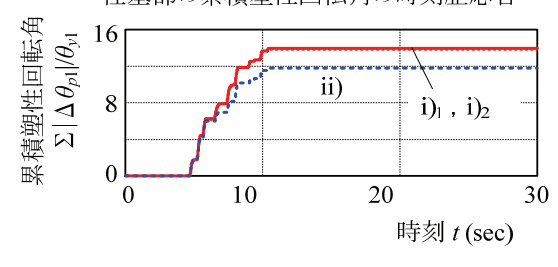

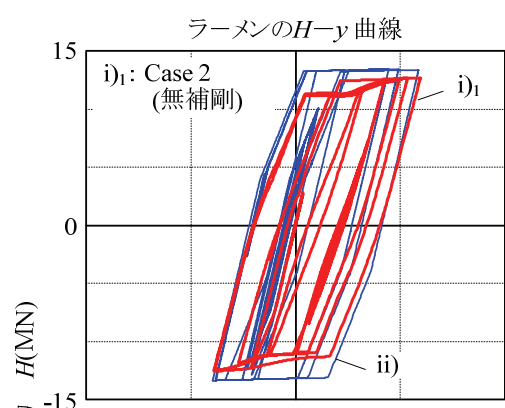

$\mathrm{R}^{-15}$

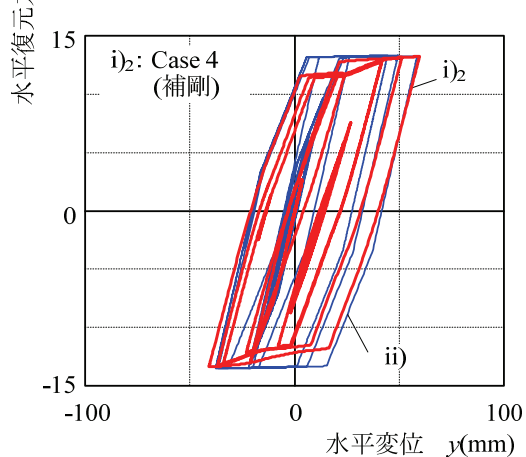

(a) はり中央のせん断崩壊先行型ラーメン $\left(y_{\max E} / y_{p 1}=6, y_{\mathrm{p} 2} / y_{p 1}=0.5\right)$
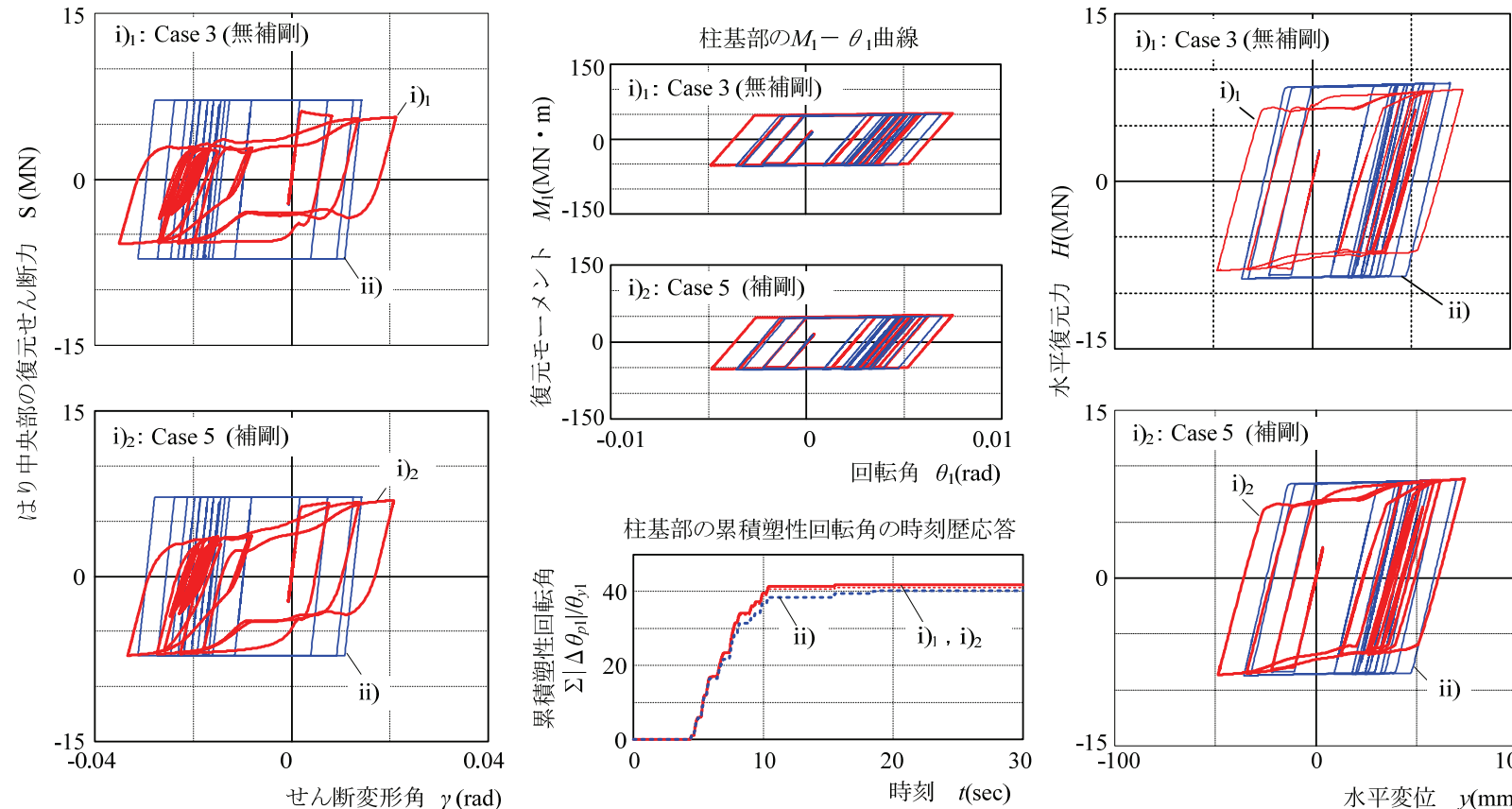

回転角 $\theta_{1}(\mathrm{rad})$

柱基部の累積塑性回転角の時刻歴応答

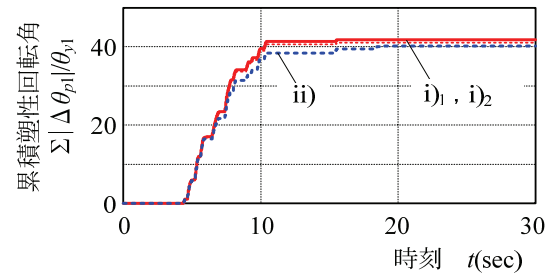

(b) 柱基部とはり中央の同時崩壊型ラーメン $\left(y_{\max E} / y_{p 1}=12, y_{\mathrm{p} 2} / y_{p 1}=1\right)$

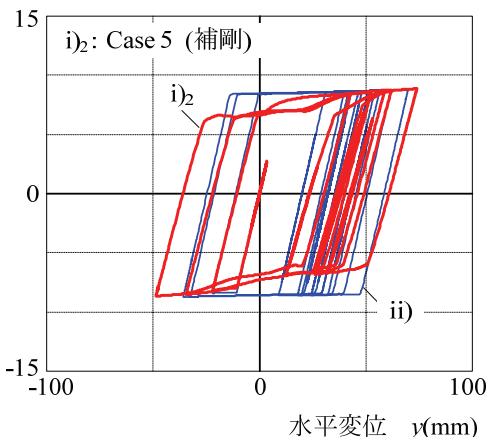

図-9 箱形ばりのせん断座屈崩壊を伴う一層門形ラーメンの地震応答性状 


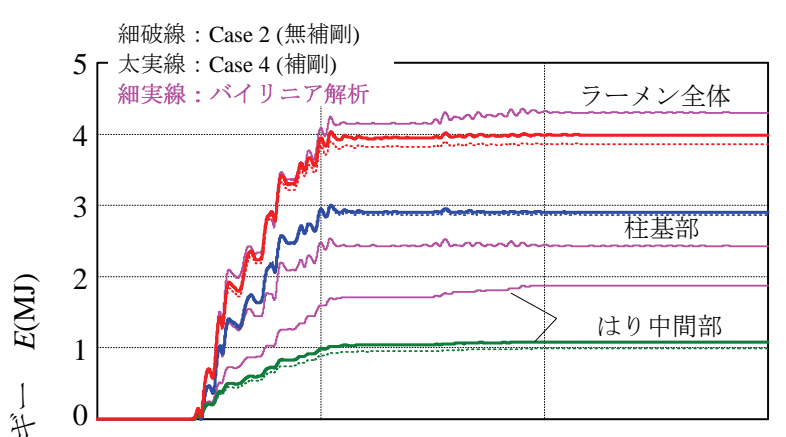

(a) はり中間部の先行崩壊 $\left(y_{\max } / y_{p 1}=6, y_{\mathrm{p} 2} / y_{p 1}=0.5\right)$

N

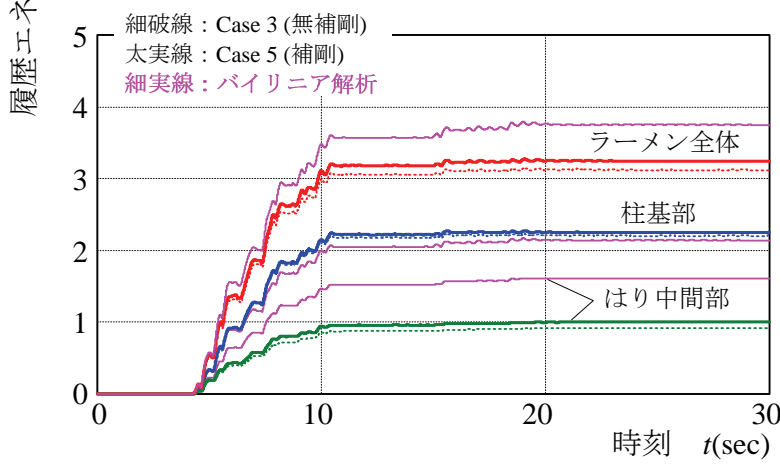

(b)柱基部・はり中間部の同時崩壊（ $\left.y_{\max E} / y_{p 1}=12, y_{\mathrm{p} 2} / y_{p 1}=1\right)$

図-10 各部の履歴消費エネルギーの時刻歴応答

て, 復元せん断力がバイリニア解析の結果に比べて, 大 きく低下していることがわかる，これは，幅厚比が大き い無補剛フランジプレートの Case 2，3 て顕著であり， せん断座屈後の耐力上昇も小さい. 一方, フランジプレ 一トを縦補剛材で適切に補剛した Case 4，5 は，座屈後 に復元せん断力がほぼ降伏せん断力のレベルにまで上昇 している. このことから, フランジプレート厚が同程度 であれば，腹板の斜め張力場形成時には，補剛されたフ ランジプレートの方がアンカーとしての効果が大きくな ると言える.

\section{b) 水平復元力 $H$ 一変位 $y$ 曲線}

はり先行崩壊型の Case 2 では, 腹板がせん断座屈する と, 水平復元力 $H$ の最大応答值がバイリニア解析に比 ベて低下している.しかし，補剛フランジプレートの Case 4 では腹板のせん断耐力上昇も大きいため, 復元力 は塑性崩壊荷重 $H_{p}$ 付近にまで達している.

柱基部とはり中間部が同時崩壊する Case 3，5 では, 弾性・除荷域加塑性域に入るとき，耐力低下が顕著に 現れている. しかし，Case 5 のように， $S$ 一 $\gamma$ 曲線のせん 断耐力の上昇に対応して, 復元力も上昇している.

\section{c） 柱基部の復元モーメント $M_{1}$ 一回転角 $\theta_{1}$ 曲線と累積 塑性回転角の時刻歴応答}

Case 2，4の $M_{1}-\theta_{1}$ の履歴ループはバイリニア解析と 大差ないように見えるが，それらの累積塑性ひずみの間 には差異がある.はり中央のせん断座屈崩壊によって, 柱基部の塑性ひずみが約 15\%大きくなっている，一方， Case 3，5では， $\theta_{1}$ の応答值はバイリニア解析のそれより

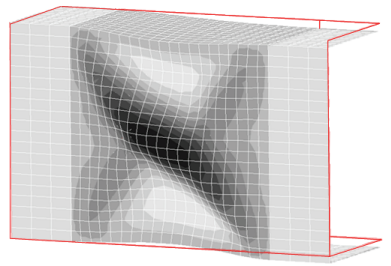

Case 2

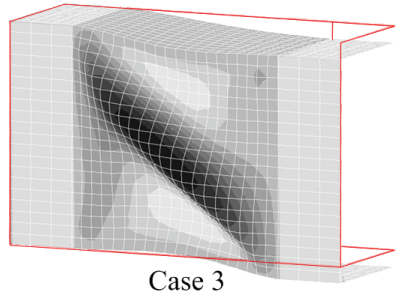

(a)無補剛フランジプレート

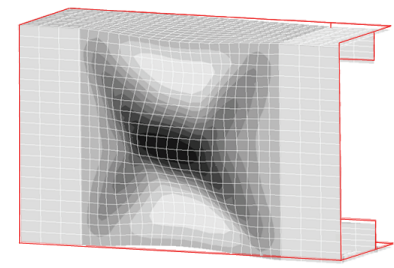

Case 4

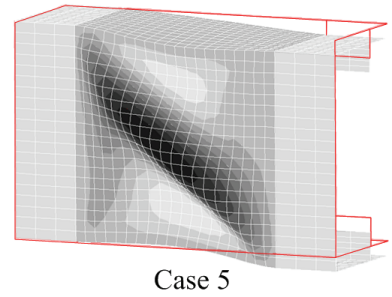

(b)補岡川フランジプレート

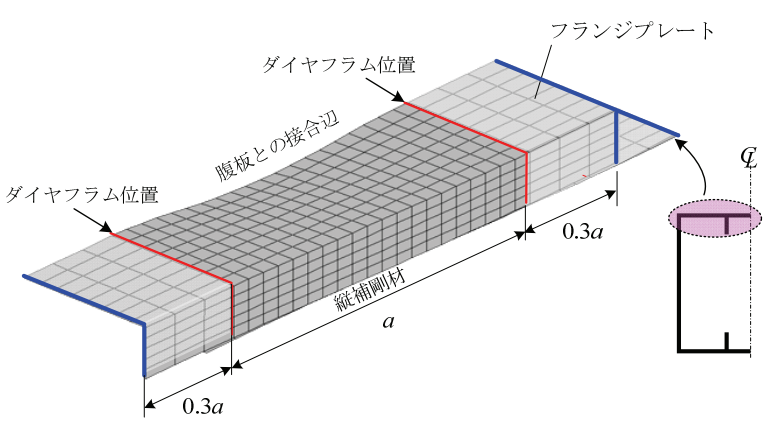

(c) 上フランジプレートの縦補岡材の変形(Case 4)

図-11 はり中央腹板の変形図（ $t=15 \mathrm{~s}$, 変形倍率 : 3 倍 $)$

も 2割程度大きいが，塑性ひずみの累積はバイリニア解 析の結果と大差ない。すなわち，同時崩壊の場合は，は りのせん断座屈による耐力変動が柱基部の損傷に及ぼす 影響は小さいと言える ${ }^{10}$.

なお，塑性変形の累積は時刻 $t=$ 約 $20 \mathrm{~s}$ までに起こっ ており, それ以降は塑性変形がほとんど現れていない.

\section{（3）各部の履歴消費エネルギーに関する解析結果と考 察}

ラーメン各部の履歴消費エネルギー(以下，履歴エネ ルギーと略す）の時刻歷応答を図-10にまとめる.

この図から, Case 2〜5 のいずれの場合も, 箱形ばり 中央がせん断座屈したことにより，その履歴エネルギー はバイリニア解析の結果を 30～40\%も下回っていること がわかる. はり中央が先行崩壊する Case 2, 4 では, そ の低下分の $60 \%$ 程度が柱基部で消費された形になって いる. 一方，はり中央と柱基部が同時崩壊する Case 3, 5 の場合, はり中央のエネルギーの変動は Case 2, 4 と 同様であるが，柱基部のそれはバイリニア解析結果と大 差ない.この点は, 文献 10)でも指摘したように, はり 中央と柱基部が同時に塑性化する場合，はり中央のせん 断崩壊が柱基部の塑性変形性状に及ぼす影響は小さい. 


\section{（4）はり中央部の損傷に関する結果と考察}

時刻 $t=15 \mathrm{~s}$ のときのはり中央部の変形図を図-11 に示 す. また，フランジプレート接合辺の腹板高さ方向の凹 夕量 $\Delta b_{w}$ （=腹板上下の凹み量の和） と軸方向変位 $\Delta a$ の時刻歴応答を図-12に比較する.

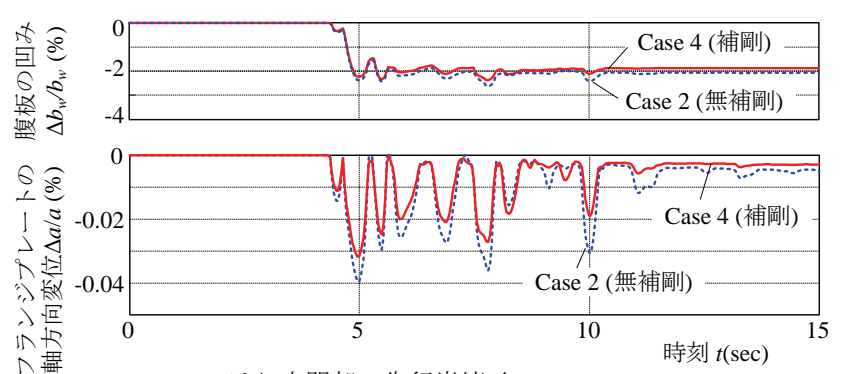

(a) はり中間部の先行崩壊 $\left(y_{\operatorname{maxE}} / y_{p 1}=6, y_{\mathrm{p} 2} / y_{p 1}=0.5\right)$

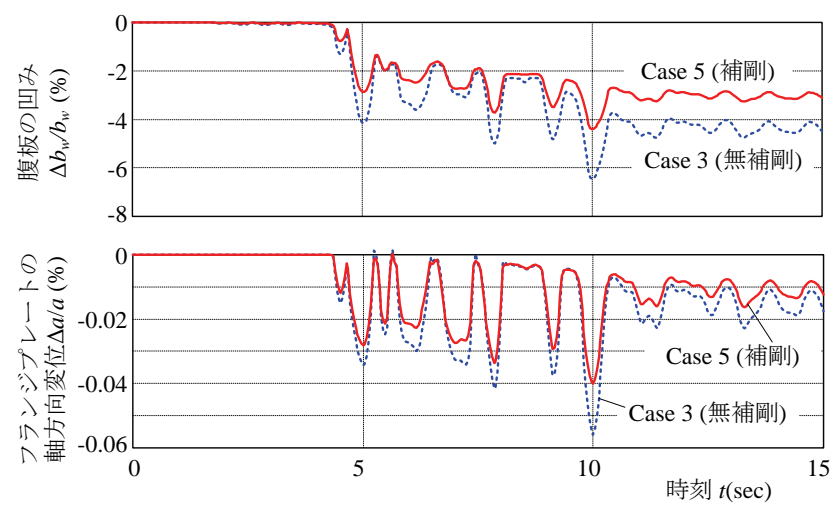

(b) 柱基部・はり中間部の同時崩壊 $\left(y_{\operatorname{maxE}} / y_{p 1}=12, y_{\mathrm{p} 2} / y_{p 1}=1\right)$

図-12 フランジプレートと腹板の変形の時刻歴応答
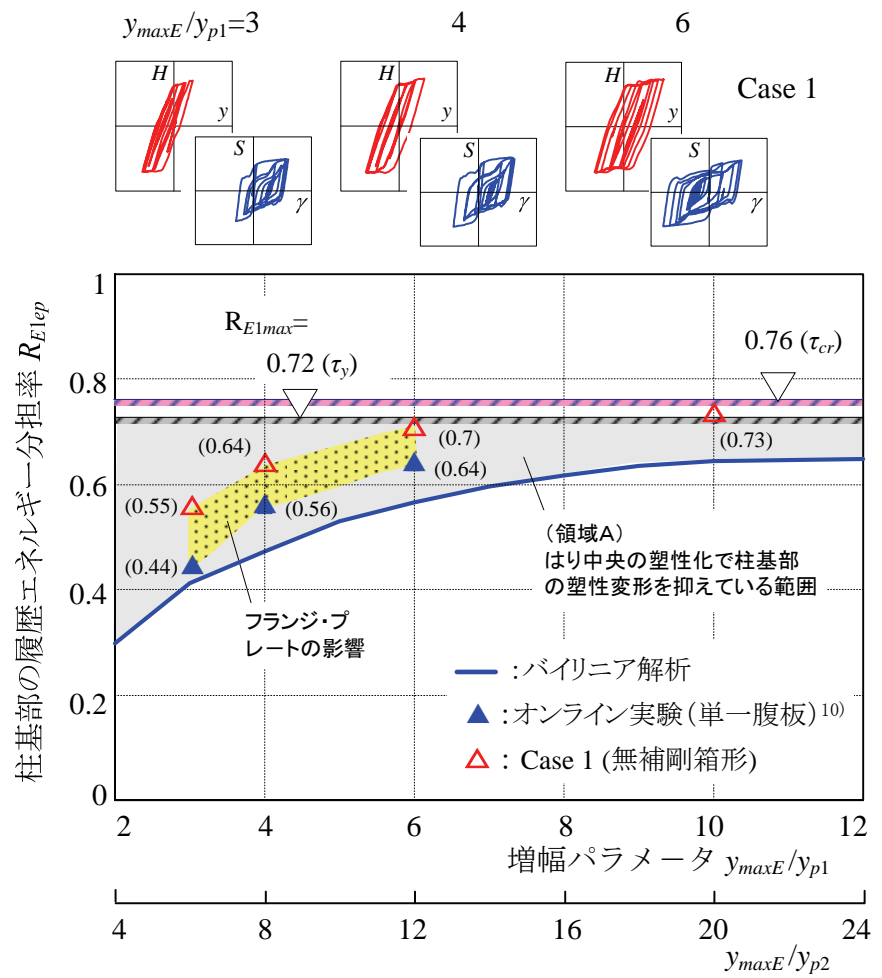

$\begin{array}{ll}\text { (a) オンライン実験結果との比較 } & \text { (b) フランジ・プレートの縦補剛材の曲 } \\ \text { 図-13 } & \text { はり中央がせん断崩壊するときの柱基部の履歴エネルギー分担率の変動 }\left(y_{p 2} / y_{p 1}=0.5\right)\end{array}$
まず，図-11 からわかるように，腹板には，大きなせ 儿断座屈たわみが発生している，とくに，無補剛の Case 2，3 では，フランジプレートが大きく内側に引き 込まれている様子がわかる，フランジプレートを補剛し た Case 4, 5でも, 同様な変形が観察できる.

つぎに，図-12 から，フランジプレートを補剛した Case 4, 5 では, 腹板の凹み量とフランジプレートの軸 方向変位ともに, Case 2, 3 に比して小さく, フランジ プレートの補剛・無補剛の違いが現れていることがわか る. すなわち, Case 2 と 4, および, Case 3 と 5について 腹板の凹み量を比較すると, $t=$ 約 $15 \mathrm{~s}$ のとき, Case 4 は 2 の約 90\%，Case 5 は 3 の約 65\%に減少している．また， フランジプレートの軸方向変位は, 最大応答值で見ると, Case 4 は 2 の約 60\%, Case 5 は 3 の約 65\%に減少してい る.

したがって，幅厚比の大きいフランジプレートを縦補 剛材で補剛すると, せん断座屈による腹板の凹み量, な らびに，フランジプレートの軸方向変位を抑える効果が 顕著になると言える.

\section{4. 柱基部との履歴消費エネルギ一分担特性から 見たはり中央部のせん断崩壊について}

入力地動加速度の大小による柱基部の履歴エネルギー の変動，および，変位応答の大小による柱基部とはり中
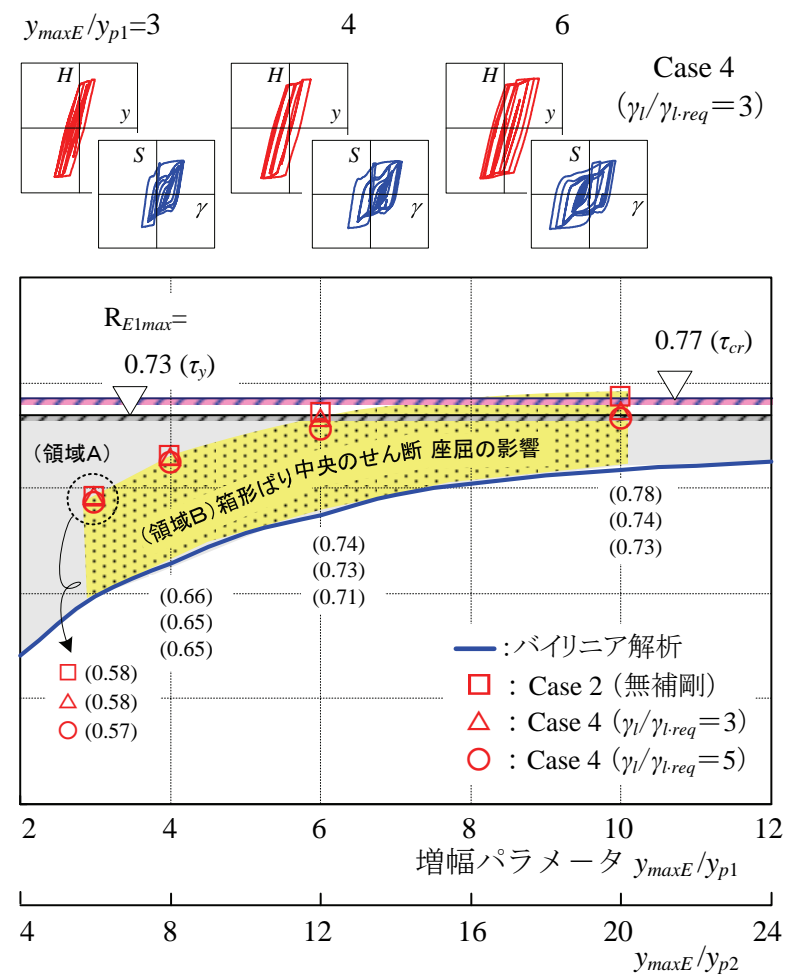

(b) フランジ・プレートの縦補剛材の曲げ剛比による変動 
央の履歴エネルギー分担の変動について考察する.なお, 3. (2) C), (3)の結果を踏まえて, 以下では, はり中央部が 先行崩壊するラーメンに着目している.

\section{（1）入力加速度増大によるラーメン各部の履歴エネル ギ一分担率の変動}

Case 1，2,4 4 の解析モデルを用いて，増幅パラメータ が $y_{\max } / y_{p 1}=3 ， 4 ， 6$ および 10 となるように，地動加速度 を増幅し, 解析を行った. Case 4 については, 縦補剛材 の曲げ剛比 $\gamma_{1}$ を必要剛比 $\gamma_{\text {req }}$ の 5 倍に設定した解析も行 った. $y_{\operatorname{maxE}} / y_{p 1}$ と柱基部の履歴エネルギー分担率 $R_{\text {Elep }}$ (=柱基部の履歴エネルギーノラーメン全体の履歴エネ ルギー）の変動を図-13 に示す，この図には，応答の大 小がわかるように $H-y, S-\gamma$ 曲線の概略図を示し，か つ, オンライン実験 $(\boldsymbol{\Delta})$ と仮動的解析 $(\square, \bigcirc, \triangle)$ の結果は数值でも示している.

ここで，図中の $R_{E 1 \max }=0.72 ， 0.73\left(\tau_{y}\right)$ の境界線は, 次式で求めた柱基部のエネルギー分担率である ${ }^{10}$.

$$
R_{E 1 \max }=\frac{1}{1+(l / a)\left(M_{p 2} / M_{p 1}\right)}
$$

上式は，柱基部とはり中央で塑性変形が進行する塑性崩 壊メカニズム形成時の柱基部の履歴エネルギー分担率で ある. また， $R_{E \mid \max }=0.76 ， 0.77\left(\tau_{\sigma}\right)$ の境界線は，上式 のバネ 2 の塑性モーメント $M_{p 2}$ の計算で（付録の式(A.4) 参照），腹板のせん断降伏点 $\tau_{y}$ の代わりに，せん断座屈 応力 $\tau_{r}$ (付録 A.2 参照) を用いて求めた参考值である.

さらに，図中の領域 A は，文献 10)で示したように, せん断崩壊するはり中央部がエネルギー吸収部材として 機能し, 柱基部の塑性変形を抑える範囲を指している. これは，はり中央が先行降伏し，柱基部が塑性化しない， または塑性化しても塑性変形が小さい復元力一変位の履 歴ループにおいては，はり中央がエネルギー吸収部材と して働き，その履歴エネルギ一量が増えるというもので ある (図-14参照)。

この図から，以下のことが考察できる.

まず，図-13(a)の Case 1 の結果（ $\triangle$ 印）は，オンライ ン実験と 15〜25\%の差異がある。これは，フランジプ レートが剛の条件のオンライン実験結果に比べて, せん 断座屈の影響で，はり中央のせん断力一せん断変形角曲 線の履歴ループの面積（=履歴エネルギー）が小さくな ったためである.

つぎに，図-13(b)を見ると，Case 2，4 の柱基部では， エネルギー分担率がバイリニア解析の結果を大きく上回 っており, 箱形ばりのせん断座屈崩壊に起因して塑性変 形が大きくなっている. 分担率は, 増幅パラメータ $y_{\operatorname{maxE}}$ $y_{p 1}=$ 約 6 の段階で塑性崩壊の分担率 $R_{E 1 \text { max }}$ (座屈応力 $\tau_{\sigma}$ を考慮した值）の付近にまで達している，また，Case 4 $a:$ はり中央部がせん断降伏する点 $b$ : 柱基部が塑性化する点

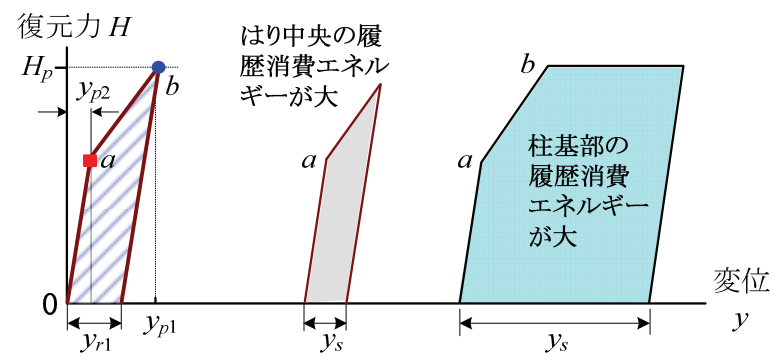

$\begin{array}{ll}\text { (a) } y_{r 1} \text { の定義 } & \text { (b) ある半サイクルの履歴ループ }\end{array}$

図-14 復元力一変位の履歴ループと変位応答スパン $y_{s}$ (Case 2, $4: y_{p 2} / y_{p 1}<1$ )

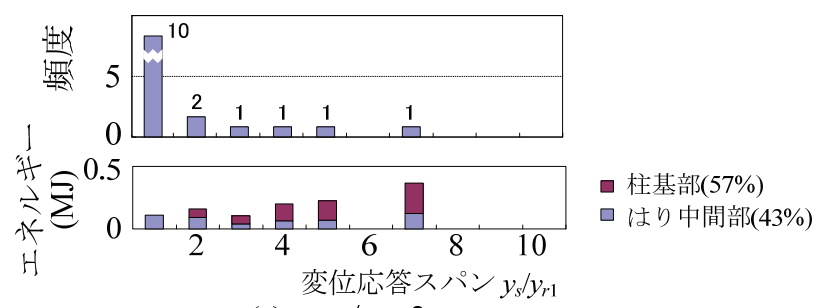

(a) $y_{\max E} / y_{p 1}=3$

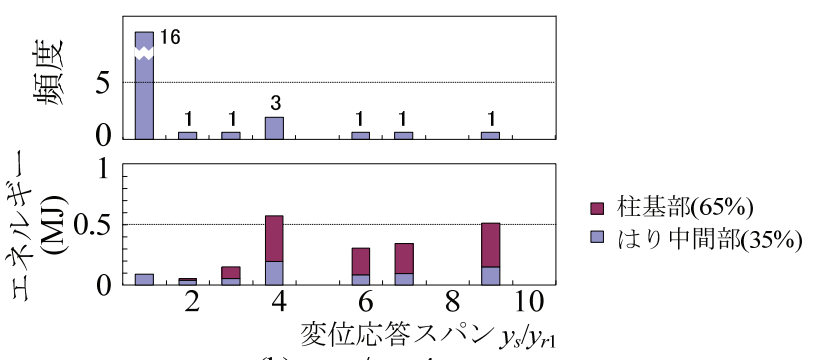

(b) $y_{\max E} / y_{p 1}=4$

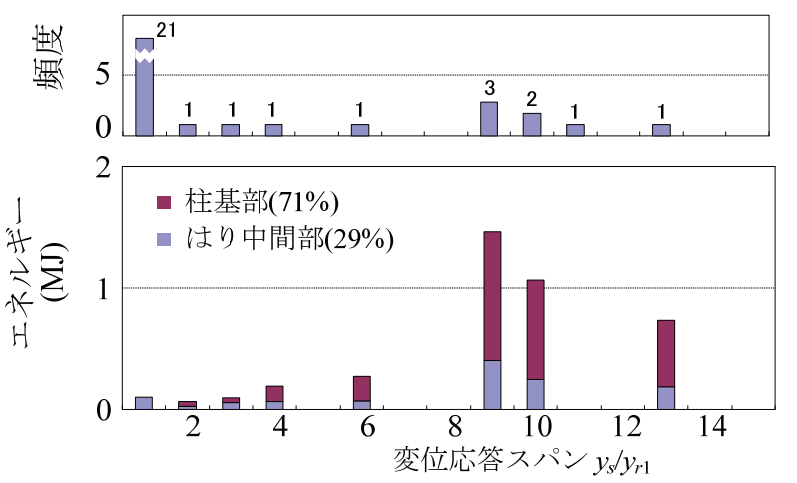

(c) $y_{\max E} / y_{p 1}=6$

図-15 変位応答スパンとラーメン各部の履歴エネ ルギー分担率 (Case $4, y_{p 2} / y_{p 1}=0.5$ )

で，フランジプレートの縦補剛材の曲げ岡比 $\gamma_{1}$ 必要剛 比 $\gamma_{\text {req }}=3,5$ の結果を比較すると, 両者の差異は非常に 小さい. 無補剛フランジプレートの Case 2 の場合, はり 中央のせん断耐力の上昇が小さいため（図-9 参照）, 履歷エネルギーの消費能力が落ち，柱基部のエネルギー 分担率は補剛フランジプレートの場合よりも約 $10 \%$ 大 きくなっている.

以上から，箱形ばり中央部のせん断座屈崩壊が早期に 起こって, せん断而力の落ち込みが大きく, 斜め張力場 
形成による耐力上昇が小さく，履歴曲線の囲む面積が小 さくなる場合，柱基部の塑性変形を抑えるエネルギ一吸 収部材としての役割 $\left.{ }^{10}\right)$ は，あまり期待できないというこ とが結論できる，なお，はり中央部がせん断座屈崩壊す るとき，その履歴エネルギー分担率は，式(11)で腹板の 座屈応力 $\tau_{c r}$ を用いて算出した $R_{E 1 \max }$ を用いて，1- $R_{E I \max }$ で評価してもよいと考える.

\section{(2) ラーメンの変位応答スパンと各部の履歴エネルギ一 分担の関係}

上記の結果を補足するため，ラーメンの復元力 $H$ 一変 位 $y$ が描く半サイクル毎の履歴ループの大小によって, 柱基部とはり中央部の履歴エネルギー分担がどのように 変動するかを調べた。 ここで，履歴ループの大きさは, 図-14 に示寸ように，復元力 $H=0$ の軸を i)負から正側に 横切る点〜正から負側に横切る点までの半サイクル，あ るいは，ii)正から負側に横切る点〜負から正側に横切る 点までの半サイクルではかり，これに対応する変位応答 スパン $y_{s}$ を調ベた。

Case 4 で増幅パラメータ $y_{\operatorname{maxE}} / y_{p 1}=3 ， 4 ， 6$ とした解析 結果から，スパン $y_{s}$ のヒストグラム，および，それに対 応する柱基部とはり中央部の履歴エネルギーの変動を図 -15 にまとめる. ここで， $y_{s}$ は，柱基部の降伏変位 $y_{p 1}$ (図-14(a)参照) に対応する残留変位 $y_{r 1}$ で無次元化して いる.

この図から， $y_{\max } / y_{p 1}=3 ， 4 ， 6$ の順に地動加速度が大 きくなると, 変位応答スパンの発生頻度が大きい方にシ フトすることがわかる。、いずれの場合も，スパン $y_{s} / y_{r 1}$ $=1 \sim 2$ の履歴ループの発生頻度が高いが，はり中間部 のみの塑性変形であるため，この範囲での履歴エネルギ 一は小さい. また，スパン $y_{s} / y_{r 1}$ の増大に伴って，はり 中央よりも柱基部のエネルギ一分担率が大きくなってい る．地動加速度が大きくなると，復元力一変位が大きな 履歴ループを呈するため，柱基部の履歴エネルギー分担 は 57\%，65\%，71\%と大きくなり，はり腹板によるエ ネルギー吸収の割合は小さくなる。これは，(1)で述心゙ たとおりである.

\section{5. まとめ}

本論文は，オンライン実験の実験プロセスを汎用 FEM コードの構造解析ソフトで仮想化し，箱形ばり中 央がせん断崩壊する鋼一層門形ラーメンの地震応答解析 を行ったものである. 本文で得られた結論を以下にまと める.

1) 箱形ばり中央部を薄肉シェル有限要素でモデル化し て弾塑性有限変位解析を行うプロセスを構築し，才
ンライン実験に準じて, 門形ラーメンの地震応答解 析を進める仮動的な解析手法を示した.

2) 補剛されたフランジプレートを有する箱形ばり中央 部に対しては, 縦補剛材の影響を考慮して, 中央パ ネルを延長した FEM解析モデルが有効である.

3) 幅厚比の大きいフランジプレートの縦補剛材による 補剛は，せん断座屈による腹板上下の凹み量とフラ ンジプレートの軸方向変位を抑える効果がある.

4) せん断崩壊する箱形ばりにおいて，フランジプレー トの縦補剛材の曲げ岡比の変動（必要剛比の 3〜5倍 の範囲）が柱基部の塑性変形性状や履歴エネルギー 分担に及ぼす影響は小さい.

5) 箱形ばり中央が早期にせん断座屈崩壊するとき，抵 抗せん断力の低下・変動が著しくなると, 履歴エネ ルギーが低下し，はり中央部には，柱基部の塑性変 形を抑えるエネルギー吸収部材としての効果を期待 できない.

6)このとき，はり中央部の履歴エネルギー分担の下限 は，はり腹板の降伏点をせん断座屈応力に置き換え た塑性崩壊メカニズムによって，ほぼ評価できる.

謝辞 : 本研究を実施するにあたり, 平成 20〜22 年度の 科学研究費補助金・基盤研究 C（課題番号 20560452）, ならびに，神戸市立工業高等専門学校の平成 22 年度研 究援助金の補助を受けた。ここに記して，謝意を表しま す。

\section{付録 A.1 門形ラーメン各部のバネ定数と塑性モ ーメントの設定}

本文で解析したラーメン各部のバネ 1 3 のバネ定数 $k_{1} \sim k_{3}$ と塑性モーメント $M_{p 1} \sim M_{p 3}$ は, 以下にしたがって 設定している.

\section{(1) 回転バネのバネ定数 $k_{i}$ の算定}

はり中間部のバネ 2 のバネ定数 $k_{2}$ は，式(1)を参考にし て, 次式で表わすことができる.

$$
k_{2}=2 G b_{w} t_{w} \times \frac{a}{2}
$$

ここに, $G$ : 腹板のせん断弾性係数, $b_{w}$ : 腹板高さ, $t_{w}:$ 腹板厚, $a$ : せん断崩壊する区間長である.

隅角部のバネ 3 につては，はり部材が両端で逆曲げ モーメントを受ける場合を想定して決めた. すなわち, 板厚が大きく, 補強された隅角部近傍のはりの断面二次 モーメント $I_{3}$ として，はり中間部の断面二次モーメント $I_{2}$ の 2.5 倍程度を仮定し ${ }^{21)}$ ，次式から $k_{3}$ を求めた.

$$
k_{3}=\frac{6 E I_{3}}{l}
$$



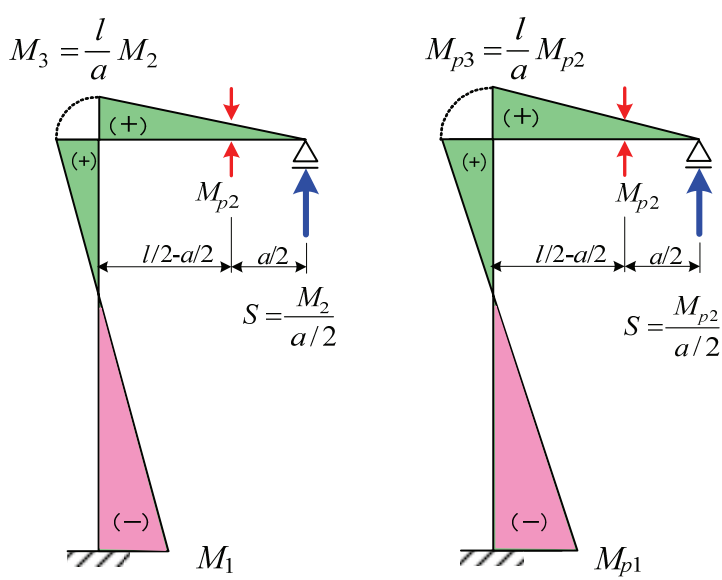

(a) 弾性変形時

(b) 崩壊メカニズム形成時

図-A1 はり・柱部材の想定曲げモーメント分布

さらに，柱基部の回転バネ $k_{1}$ は，柱頭部に水平外力 を受けるラーメンの柱基部と隅角部に発生するモ一メン 卜比 $M_{3} / M_{1}$ を 0.75 に仮定して，次式から求めた（図-A1 参照).

$$
k_{1}=\frac{M_{1}}{M_{3}} \frac{k_{2} k_{3}}{k_{2}+(a / l)^{2} k_{3}}
$$

\section{(2) バネの塑性モーメント $M_{p i}$ の算定}

はり中間部のバネ 2 の塑性モーメント $M_{p 2}$ は，2. (1)を 参照すると, 腹板の降伏せん断応力 $\tau_{y}$ を用いて, 以下の ように算出できる.

$$
M_{p 2}=2 b_{w} t_{w} \tau_{y} \frac{a}{2}=b_{w} t_{w} \tau_{y} a
$$

柱基部の塑性モーメント $M_{p 1}$ は，柱基部とはり中間部 が降伏するときの水平変位の比 $y_{p 2} 2 y_{p 1}$ をパラメータにし て算定する. 文献 10)によると，柱基部の塑性モーメン ト $M_{p 1}$ は次のように表すことができる.

$$
M_{p 1}=\frac{k_{1} k_{2}+(a / l)^{2} k_{1} k_{3}}{k_{2} k_{3}} \cdot \frac{l}{a} \cdot \frac{y_{p 1}}{y_{p 2}} \cdot M_{p 2}
$$

隅角部については，図-A1(b)に示すように，ラーメンの 柱基部とはり中間部が塑性化するとき, 隅角部の曲げモ 一メントの上昇が頭打ちになることから，弾性状態を保 つように，塑性モーメント $M_{p 3}$ を設定した。

\section{付録 A.2 腹板のせん断座屈耐荷力について}

せん断力を受ける腹板の耐荷力は，たとえば 文献 22) を参考にすると, 表-1 に示した無次元幅厚比 $R_{\tau}$ をパラ メータにして，次のように表すことができる.

$$
\begin{aligned}
\tau_{c r} / \tau_{y} & =1 & & \left(R_{\tau}<0.6\right) \\
& =1.143-0.238 R_{\tau} & & \left(0.6<R_{\tau} \leqq \sqrt{2}\right)
\end{aligned}
$$

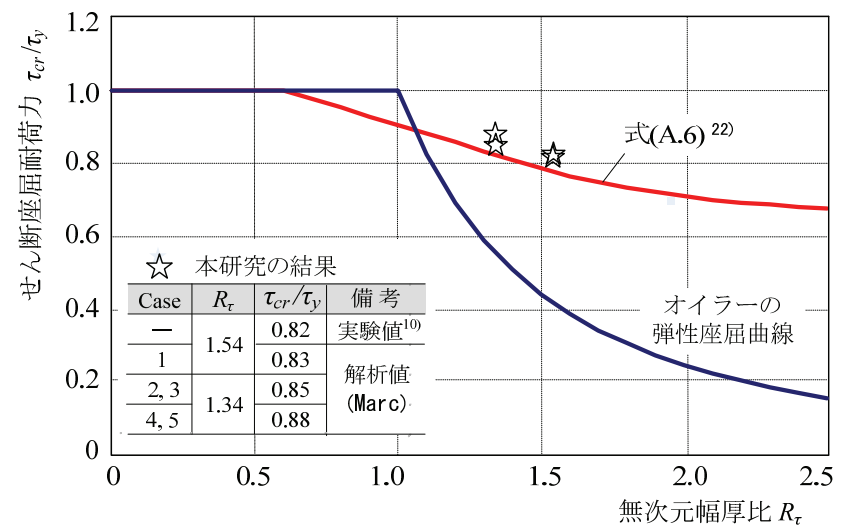

図-A2 本研究で解析した腹板の座屈而荷力

$$
=0.388 / R_{\tau}+0.612 \quad\left(\sqrt{2}<R_{\tau}\right)
$$

MARCによる箱形ばり中央の $\tau-\gamma$ 曲線において，処女 履歴ループの折れ曲がりから座屈耐荷力を求め, 上式と 比較すると，図-A2 のとおりである。この図から，上式 は，本研究の解析值を比較的よく近似していることがわ かる.

\section{参考文献}

1) 伯野元彦, 四俵正俊, 原司：計算機により制御され たはりの動的破壊実験, 土木学会論文報告集,

No.171, pp.1-9, 1969.1.

2) 家村浩和：ハイブリッド実験の発展と将来, 土木学 会論文集，No.356/I-3，pp.1-10，1985.4.

3) 伯野元彦, 岡田恒雄, 高梨晃一, 土岐憲三, 池田尚 治, 家村浩和, 片田敏行：ハイブリッド実験応用マ ニュアル，平成元年度科学研究費補助金（総合研究 (A) ) 研究成果報告書，1990.3.

4) 才塚邦宏, 伊藤義人, 木曽英滋, 宇佐美 勉: 相似則 を考慮したハイブリッド地震応答実験手法に関する 考察，土木学会論文集，No.507/I-30，pp.179-190， 1995.1.

5) 小畑 誠, 後藤芳顕: 橋脚や柱等を対象とした 3 次元 擬似動的実験装置の開発, 土木学会論文集, No.752/I-66, pp.253-266, 2004.1.

6) Bursi, O. S. and Shing, P. B.: Evaluation of some implicit time-stepping algorithms for pseudodynamic tests, Earthquake Engineering and Structural Dynamics, Vol.25, pp.333-355, 1996.

7) Hashash, Y. M. A, Ghaboussi, J., Yun, G. J. and Elnashai, A. S.: Development of software framework for MUSTSIM facilities, Integrated Computational and Experimental Simulation, 13th World Conference on Earthquake Engineering, Vancouver, BC Canada, 2004.

8) 中島正愛, 石田雅利, 安藤和博 : サブストラクチャ 仮動的実験のための数值積分法, 日本建築学会構造 系論文集，第 417 号，pp.107-117，1990.11.

9) 中島正愛, 赤澤隆士, 阪口 理 : 実験誤差制御機能を 有したサブストラクチャ仮動的実験のための数值積 分法, 日本建築学会構造系論文集, 第 454 号, pp.6171, 1993.12.

10) 山田宰, 酒造敏廣 : はりがせん断崩壊する鋼一層門 形ラーメンのオンライン実験法による地震応答解析, 
土木学会論文集 A, Vol. 65, No.2, pp.348-361, 2009.5.

11) 酒造敏廣, 山田 宰, 都築 禅 : 一層目はり中央がせん 断崩壊する鋼二層門形ラーメンのオンライン実験法 による地震応答解析, 土木学会・構造工学論文集, Vol.55A, pp.525-536, 2009.3.

12) 山田宰, 都築 禅, 酒造敏廣 : $\alpha-O S$ 法による鋼製門 形ラーメンの弾塑性地震応答解析, 大同工業大学紀 要, 第 44 巻, pp.143-149, 2008.12.

13) MSC. Software: MSC MARC2003, 日本語オンライン マニュアル, 2003.

14）山田宰, 篠瀬圭介, 酒造敏廣 : はり中央のせん断座 屈崩壊を考慮した鋼門形ラーメンの地震応答シミュ レーション, 地震時保有耐力法に基づく橋梁等構造 の耐震設計に関するシンポジウム講演論文集，第 12 回, 土木学会, pp.231-238, 2009.1.

15) 中井博, 北田俊行, 酒造敏廣 : 初期不整を有する圧 縮補剛板の局部座屈と全体座屈の連成現象について, 第 15 回マトリックス解析法・研究発表論文集, pp.325-330, 1981.7.

16) Nakai, H., Kitada, T. and Miki, T.: Interaction Curve of Thin-Walled Box Stub-Columns subjected to Compression and Bending for Applying to Overall Buckling Analysis of Columns, Proc. of the Japan Society of Civil Engineers,
Structural Eng./Earthquake Eng., Vol.2, No.2, pp.311s319s, Oct. 1985.

17) 武田八郎：せん断パネルの非弾性交番座屈実験, 鋼 構造年次論文報告集，第 2 巻, JSSC, pp.147-154, 1994.11.

18) Takeda, H.: A Fundamental study on simplified analysis of bucking load-carry capacity and deformability of girders, Doctor Thesis (Kyoto University), 2004.

19) 酒造敏廣, 山田宰, 樋口直紀: 繰り返しせん断力を 受ける鋼腹板の弾塑性応答性状に関する実験, 構造 工学論文集, Vol.53A，土木学会, pp.117-124, 2007.3.

20) 日本道路協会 : 道路示方書 - 同解説 II 鋼橋編, 丸善, 2002.

21) 中井 博, 河井章好, 吉川 紀, 北田俊行, 酒造敏廣 : 鋼製ラーメン橋脚の実績調查（上），（下），橋梁 と基礎, Vol.16, No.6, pp.35-40, 1982.6., および, Vol.16, No.7, pp.43-49, 1982.6.

22) 土木学会鋼構造委員会 : 座屈設計ガイドライン, 座 屈設計ガイドライン改定小委員会, 土木学会, 丸善, 2005.10.

(2010.12.16 受付)

\title{
EARTHQUAKE RESPONSE ANALYSIS OF STEEL PORTAL FRAMES BY PSEUDODYNAMIC SIMULATION TECHNIQUE USING A GENERAL-PURPOSE FINITE ELEMENT ANALYSIS PROGRAM
}

\author{
Toshihiro MIKI, Tomisaku MIZUSAWA, Osamu YAMADA and Tomoki TODA
}

This paper studies the earthquake response of steel portal frames when the shear collapse occurs at the centre of the beam. The pseudodynamic simulation technique for the earthquake response analysis of the frames is developed in correspondence to the pseudodynamic substructure testing method. For the thinwalled box element under shear force in the middle of beam, the numerical process is utilized by a general-purpose finite element analysis program. The numerical results show the shear collapse behaviour in stiffened box beams and corresponding restoring force - displacement relationship of frames. The advantages of shear collapse of beams for the use in frames during earthquakes are discussed from the point of view of the hysteretic energy dissipated by the column base. 